\title{
Interleukin-21 gene polymorphism rs2221903 is associated with disease activity in patients with rheumatoid arthritis
}

\author{
Damian Malinowski ${ }^{1,2}$, Agnieszka Paradowska-Gorycka ${ }^{3}$, Krzysztof Safranow ${ }^{4}$, Andrzej Pawlik ${ }^{1}$
}

\author{
${ }^{1}$ Department of Physiology, Pomeranian Medical University, Szczecin, Poland \\ 2Department of Experimental and Clinical Pharmacology, Pomeranian Medical \\ University, Szczecin, Poland \\ ${ }^{3}$ National Institute of Geriatrics, Rheumatology and Rehabilitation, Warsaw, Poland \\ ${ }^{4}$ Department of Biochemistry and Medical Chemistry, Pomeranian Medical University, \\ Szczecin, Poland
}

Submitted: 31 July 2016

Accepted: 6 December 2016

Arch Med Sci 2017; 13, 5: 1142-1147

DOI: https://doi.org/10.5114/aoms.2017.68945

Copyright (c) 2017 Termedia \& Banach

\section{Abstract}

Introduction: Interleukin-21 (IL-21) is a cytokine which plays a significant role in the pathogenesis and disease activity of rheumatoid arthritis (RA). Genetic polymorphisms in the IL-21 gene may alter the synthesis of IL- 21 . The aim of this study was to examine IL-21 and IL-21R polymorphisms in patients with RA.

Material and methods: We examined 422 patients with RA and 338 healthy controls. Single nucleotide polymorphisms (SNPs) within the IL-21 (rs6822844 $\mathrm{G}>\mathrm{T}, \mathrm{rs} 6840978 \mathrm{C}>\mathrm{T}, \mathrm{rs} 2221903 \mathrm{~T}>\mathrm{C}$ ) and IL-21R (rs2285452 G>A) genes were genotyped using TaqMan genotyping assays.

Results: There were no statistically significant differences in the distribution of studied genotypes and alleles between RA patients and the control group. To examine whether IL-21 polymorphisms affect disease activity in RA patients, we compared the distribution of IL-21 genotypes between patients with DAS28 $\leq 2.5$ (patients with remission of disease symptoms) and patients with DAS28 > 2.5 (patients with active RA). Among patients with DAS28 > 2.5, increased prevalence of rs2221903 CT and CC genotypes was observed $(\mathrm{OR}=1.54 ; 95 \% \mathrm{Cl}: 1.04-2.28 ; p=0.035)$.

Conclusions: The results of this study suggest that IL-21 and IL-21R gene polymorphisms are not risk loci for RA susceptibility, whereas the IL-21 rs2221903 polymorphism is associated with disease activity.

Key words: rheumatoid arthritis, interleukin-21, polymorphism.

\section{Introduction}

Rheumatoid arthritis is a multifactorial disease leading to joint destruction and numerous extra-articular manifestations. In the pathogenesis of rheumatoid arthritis (RA), proinflammatory cytokines play a significant role, inducing inflammatory responses as well as the release of other mediators of inflammation. Interleukin-21 (IL-21), an immunomodulatory type 1 cytokine, is produced by CD4+ T cells including T follicular helper cells, Th17 cells and natural killer (NK) T cells and has pleiotropic effects on both innate and adaptive immune responses [1]. Interleukin-21 increases the proliferation of activated CD4+ and CD8+ T cells and

\author{
Corresponding author: \\ Andrzej Pawlik MD, PhD \\ Department of Physiology \\ Pomeranian Medical \\ University \\ 72 Powst. Wlkp. St \\ 70-111 Szczecin, Poland \\ Phone: +48914661601 \\ E-mail: pawand@poczta. \\ onet.pl
}


inhibits the differentiation of inducible regulatory T cells [2, 3]. Moreover, IL-21 can directly act on $B$ cells, leading to activation of the immune response. Thus, the effect of IL-21 on B cells may contribute to the development of autoimmune diseases $[4,5]$. Numerous studies suggest that IL-21 is a cytokine playing an important role in RA pathogenesis and in the development and maintenance of inflammatory status in joints and tissues in RA patients $[6,7]$. Previous studies have revealed increased levels of IL-21 in RA patients, which correlated with disease activity parameters [8].

It has been shown that the expression of IL-21 and IL-21R may be modulated by the genetic polymorphisms in genes coding IL-21 and IL-21R [9, 10]. Genetic polymorphisms have been studied in various diseases, as factors associated with increased disease risk [11-14]. The aim of this study was to examine IL-21 and IL-21R polymorphisms in patients with RA compared with control subjects.

\section{Material and methods}

\section{Subjects}

We examined 422 patients (340 female, 82 male, mean age: $57.5 \pm 12.5$ years) with rheumatoid arthritis diagnosed according to the criteria of the American College of Rheumatology/European League against Rheumatism [15]. Consenting RA patients treated between 2010 and 2013 in the Department of Rheumatology, County Hospital in Szczecin, Poland were enrolled in the study. All subjects were Caucasian, from the Pomeranian region of Poland. The patients were treated with low doses of methotrexate and glucocorticosteroids.

Disease activity was determined on the basis of the DAS28 score. Those patients with DAS28 $\leq 2.5$ were classified as subjects in remission of disease symptoms, while those with DAS28 > 2.5 were classified as subjects with an active form of RA [16, 17].

The control group was selected randomly from the population of the Pomeranian region of Poland and consisted of 338 healthy Caucasian subjects (261 female, 77 male) without autoimmunological diseases (mean age: $60.6 \pm 15.4$ years). The study was approved by the ethics committee in Pomeranian Medical University, Szczecin, Poland, and written informed consent was obtained from all subjects.

\section{Genotyping}

DNA was extracted from $200 \mu \mathrm{l}$ whole blood samples using a GeneMATRIX Quick Blood DNA Purification Kit (EURx, Poland). SNPs within IL-21 (rs6822844 G>T, rs6840978 C>T, rs2221903 T>C) and IL-21R (rs2285452 G>A) genes were geno- typed using pre-validated TaqMan genotyping assays (Life Technologies, USA). Fluorescence data were captured using a 7500 Fast Real-Time PCR System (Applied Biosystems, USA).

\section{Statistical analysis}

Chi-square $\left(\chi^{2}\right)$ and Fisher's exact tests were used to compare genotype and allele frequencies between the study groups. $P<0.05$ was considered statistically significant. The age at onset was compared between genotypes using the Kruskal-Wallis test.

\section{Results}

Clinical and demographic data of patients and the control group are shown in Table I. The distributions of studied genotypes were in Hardy-Weinberg equilibrium and are shown in Table II. As shown in Table II, there were no statistically significant differences in the distribution of studied genotypes and alleles between RA patients and the control group.

To examine whether IL-21 polymorphisms affect disease activity in RA patients, we compared the distribution of IL-21 genotypes between patients with DAS28 $\leq 2.5$ (patients with remission of disease symptoms) and patients with DAS28 $>2.5$ (patients with active RA). Among patients with DAS28 > 2.5, the prevalence of rs2221903 $\mathrm{CT}$ and CC genotypes was revealed $(\mathrm{OR}=1.54$; 95\% Cl: 1.04-2.28; $p=0.035$ ) (Table III).

Additionally, we examined the associations between the studied polymorphisms and clinical pa-

Table I. Clinical and demographic parameters of patients with rheumatoid arthritis (RA) and control group

\begin{tabular}{|lcc|}
\hline Parameter & RA & $\begin{array}{c}\text { Control } \\
\text { group }\end{array}$ \\
\hline$N$ & 422 & 338 \\
\hline Sex (F/M) & $340 / 82$ & $261 / 77$ \\
\hline $\begin{array}{l}\text { Age [years] } \\
\text { Mean } \pm \text { SD }\end{array}$ & $57.47 \pm 12.45$ & $60.62 \pm 15.35$ \\
\hline $\begin{array}{l}\text { Disease duration } \\
\text { Mean } \pm \text { SD }\end{array}$ & $10.07 \pm 8.32$ & - \\
\hline $\begin{array}{l}\text { Age at disease onset } \\
\text { Mean } \pm \text { SD }\end{array}$ & $47.40 \pm 13.22$ & - \\
\hline $\begin{array}{l}\text { Rheumatoid factor } \\
\text { (positive) }\end{array}$ & $75.36 \%$ & - \\
\hline Erosive RA & $80.09 \%$ & - \\
\hline $\begin{array}{l}\text { Extra-articular } \\
\text { manifestations }\end{array}$ & $17.06 \%$ & - \\
\hline $\begin{array}{l}\text { DAS28 } \\
\text { N - number of patients, } F-\text { number of females, M - number of } \\
\text { males. }\end{array}$ & & \\
\hline
\end{tabular}


Damian Malinowski, Agnieszka Paradowska-Gorycka, Krzysztof Safranow, Andrzej Pawlik

Table II. Distribution of IL-21 and IL-21R genotypes in RA patients and control group

\begin{tabular}{|c|c|c|c|c|c|c|c|c|}
\hline \multirow[t]{2}{*}{ Variable } & \multicolumn{2}{|c|}{ RA patients } & \multicolumn{2}{|c|}{ Control group } & \multirow[t]{2}{*}{$P$-value ${ }^{a}$} & & \multirow[t]{2}{*}{$P$-value ${ }^{b}$} & \multirow[t]{2}{*}{ OR $(95 \% \mathrm{Cl})$} \\
\hline & $n$ & $\%$ & $n$ & $\%$ & & & & \\
\hline \multicolumn{9}{|c|}{ IL-21 rs2221903 genotype: } \\
\hline $\mathrm{TT}$ & 174 & 41.23 & 151 & 44.67 & \multirow{3}{*}{0.60} & $\mathrm{CC}+\mathrm{CT}$ vs. TT & 0.38 & $1.15(0.86-1.54)$ \\
\hline $\mathrm{CT}$ & 193 & 45.74 & 148 & 43.79 & & CC vs. $\mathrm{CT}+\mathrm{TT}$ & 0.58 & $1.15(0.74-1.78)$ \\
\hline \multirow[t]{3}{*}{$\overline{C C}$} & 55 & 13.03 & 39 & 11.54 & & CC vs. TT & 0.41 & $1.22(0.77-1.95)$ \\
\hline & & & & & & CT vs. TT & 0.81 & $1.13(0.83-1.54)$ \\
\hline & & & & & & CC vs. CT & 0.44 & $1.08(0.68-1.72)$ \\
\hline \multicolumn{9}{|c|}{ IL-21 rs2221903 allele: } \\
\hline $\mathrm{T}$ & 541 & 64.10 & 450 & 66.57 & & & & \\
\hline C & 303 & 35.90 & 226 & 33.43 & & C vs. T & 0.30 & $1.12(0.90-1.38)$ \\
\hline \multicolumn{9}{|c|}{ IL-21 rs6822844 genotype: } \\
\hline GG & 313 & 74.17 & 255 & 75.45 & \multirow{3}{*}{0.90} & TT + GT vs. GG & 0.74 & $1.07(0.77-1.49)$ \\
\hline GT & 103 & 24.41 & 79 & 23.37 & & TT vs. GT + GG & 1.00 & $1.20(0.34-4.30)$ \\
\hline \multirow[t]{3}{*}{$\mathrm{TT}$} & 6 & 1.42 & 4 & 1.18 & & TT vs. GG & 1.00 & $1.22(0.34-4.38)$ \\
\hline & & & & & & GT vs. GG & 0.73 & $1.06(0.76-1.49)$ \\
\hline & & & & & & TT vs. GT & 1.00 & $1.15(0.31-4.22)$ \\
\hline \multicolumn{9}{|c|}{ IL-21 rs6822844 allele: } \\
\hline $\bar{G}$ & 729 & 86.37 & 589 & 87.13 & & & & \\
\hline$T$ & 115 & 13.63 & 87 & 12.87 & & T vs. G & 0.70 & $1.07(0.79-1.44)$ \\
\hline \multicolumn{9}{|c|}{ IL-21 rs6840978 genotype: } \\
\hline $\mathrm{CC}$ & 287 & 68.01 & 227 & 67.16 & \multirow{3}{*}{0.73} & $\mathrm{TT}+\mathrm{CT}$ vs. CC & 0.82 & $0.96(0.71-1.31)$ \\
\hline$\overline{\mathrm{CT}}$ & 123 & 29.15 & 104 & 30.77 & & TT vs. $C T+C C$ & 0.64 & $1.38(0.54-3.56)$ \\
\hline \multirow[t]{3}{*}{$\mathrm{TT}$} & 12 & 2.84 & 7 & 2.07 & & TT vs. CC & 0.64 & $1.36(0.53-3.50)$ \\
\hline & & & & & & CT vs. CC & 0.69 & $0.94(0.68-1.28)$ \\
\hline & & & & & & TT vs. CT & 0.48 & $1.45(0.55-3.82)$ \\
\hline \multicolumn{9}{|c|}{ IL-21 rs6840978 allele: } \\
\hline $\bar{C}$ & 697 & 82.58 & 558 & 82.54 & & & & \\
\hline$T$ & 147 & 17.42 & 118 & 17.46 & & T vs. C & 1.00 & $1.00(0.76-1.30)$ \\
\hline \multicolumn{9}{|c|}{ IL-21R rs2285452 genotype: } \\
\hline$\overline{G G}$ & 239 & 56.63 & 207 & 61.24 & & $A A+G A$ vs. GG & 0.21 & $1.21(0.90-1.62)$ \\
\hline$\overline{G A}$ & 165 & 39.10 & 110 & 32.55 & 0.12 & $A A$ vs. $G A+G G$ & 0.25 & $0.67(0.35-1.28)$ \\
\hline \multirow[t]{3}{*}{$\overline{\mathrm{AA}}$} & 18 & 4.27 & 21 & 6.21 & & AA vs. GG & 0.41 & $0.74(0.39-1.43)$ \\
\hline & & & & & & GA vs. GG & 0.10 & $1.30(0.96-1.76)$ \\
\hline & & & & & & AA vs. GA & 0.12 & $0.57(0.29-1.12)$ \\
\hline \multicolumn{9}{|c|}{ IL-21R rs2285452 allele: } \\
\hline $\bar{G}$ & 643 & 76.18 & 524 & 77.51 & & & & \\
\hline A & 201 & 23.82 & 152 & 22.49 & & A vs. G & 0.58 & $1.08(0.85-1.37)$ \\
\hline
\end{tabular}

${ }^{a} \chi^{2}$ test, ${ }^{b}$ Fisher exact test. IL-21 rs2221903, HWE: examined group $p=0.92$, control group $p=0.81$; IL-21 rs6822844, HWE: examined group $p=0.54$, control group $p=0.63 ;$ IL-21 rs6840978, HWE: examined group $p=0.87$, control group $p=0.26$; IL-21R rs2285452, HWE: examined group $p=0.14$, control group $p=0.21$. 
Table III. Comparison between patients with active RA (patients with DAS28 > 2.5) and patients in disease remission (patients with DAS28 $\leq 2.5$ )

\begin{tabular}{|c|c|c|c|c|c|c|c|c|}
\hline \multirow[t]{3}{*}{ Variable } & \multirow{2}{*}{\multicolumn{2}{|c|}{$\begin{array}{l}\text { Patients with } \\
\text { DAS28 } \leq 2.5 \\
N=173\end{array}$}} & \multirow{2}{*}{\multicolumn{2}{|c|}{$\begin{array}{l}\text { Patients with } \\
\text { DAS28 }>2.5 \\
N=249\end{array}$}} & \multirow[t]{3}{*}{$P$-value ${ }^{a}$} & & \multirow[t]{3}{*}{$P$-value ${ }^{\mathrm{b}}$} & \multirow[t]{3}{*}{ OR $(95 \% \mathrm{Cl})$} \\
\hline & & & & & & & & \\
\hline & $n$ & $\%$ & $n$ & $\%$ & & & & \\
\hline \multicolumn{9}{|c|}{ IL-21 rs2221903 genotype: } \\
\hline TT & 82 & 47.4 & 92 & 36.9 & \multirow{3}{*}{0.10} & $\mathrm{CC}+\mathrm{CT}$ vs. TT & $0.035^{\star}$ & $1.54(1.04-2.28)$ \\
\hline $\mathrm{CT}$ & 71 & 41.0 & 122 & 49.0 & & CC vs. $\mathrm{CT}+\mathrm{TT}$ & 0.56 & $0.80(0.44-1.44)$ \\
\hline \multirow[t]{3}{*}{ CC } & 20 & 11.6 & 35 & 14.1 & & CC vs. TT & 0.21 & $1.56(0.84-2.91)$ \\
\hline & & & & & & CT vs. TT & 0.06 & $0.65(0.43-0.99)$ \\
\hline & & & & & & CC vs. CT & 1.00 & $0.98(0.53-1.83)$ \\
\hline \multicolumn{9}{|c|}{ IL-21 rs2221903 allele: } \\
\hline $\mathrm{T}$ & 235 & 67.90 & 306 & 61.4 & & & & \\
\hline $\mathrm{C}$ & 111 & 32.10 & 192 & 38.6 & & C vs. T & 0.057 & $1.33(0.99-1.77)$ \\
\hline \multicolumn{9}{|c|}{ IL-21 rs6822844 genotype: } \\
\hline GG & 127 & 73.4 & 186 & 74.7 & \multirow{3}{*}{0.86} & TT + GT vs. GG & 0.82 & $1.07(0.69-1.66)$ \\
\hline GT & 44 & 25.4 & 59 & 23.7 & & TT vs. GT + GG & 1.00 & $0.72(0.13-3.96)$ \\
\hline \multirow[t]{3}{*}{$\mathrm{TT}$} & 2 & 1.2 & 4 & 1.6 & & TT vs. GG & 1.00 & $0.73(0.13-4.06)$ \\
\hline & & & & & & GT vs. GG & 0.73 & $1.09(0.70-1.71)$ \\
\hline & & & & & & TT vs. GT & 1.00 & $0.67(0.12-3.83)$ \\
\hline \multicolumn{9}{|c|}{ IL-21 rs6822844 allele: } \\
\hline G & 298 & 86.1 & 431 & 86.5 & & & & \\
\hline $\mathrm{T}$ & 48 & 13.9 & 67 & 13.5 & & T vs. G & 0.92 & $1.04(0.70-1.54)$ \\
\hline \multicolumn{9}{|c|}{ IL-21 rs6840978 genotype: } \\
\hline $\mathrm{CC}$ & 114 & 65.9 & 173 & 69.5 & \multirow{3}{*}{0.41} & $\mathrm{TT}+\mathrm{CT}$ vs. $\mathrm{CC}$ & 0.46 & $1.18(0.78-1.78)$ \\
\hline $\mathrm{CT}$ & 52 & 30.1 & 71 & 28.5 & & TT vs. CT + CC & 0.24 & $2.06(0.64-6.59)$ \\
\hline \multirow[t]{3}{*}{ TT } & 7 & 4.0 & 5 & 2.0 & & TT vs. CC & 0.24 & $2.12(0.66-6.86)$ \\
\hline & & & & & & CT vs. CC & 0.66 & $1.11(0.72-1.71)$ \\
\hline & & & & & & TT vs. CT & 0.36 & $1.91(0.57-6.36)$ \\
\hline \multicolumn{9}{|c|}{ IL-21 rs6840978 allele: } \\
\hline $\mathrm{C}$ & 280 & 80.9 & 417 & 83.7 & & & & \\
\hline $\mathrm{T}$ & 66 & 19.1 & 81 & 16.3 & & T vs. C & 0.31 & $1.21(0.85-1.74)$ \\
\hline \multicolumn{9}{|c|}{ IL-21R rs2285452 genotype: } \\
\hline GG & 88 & 50.9 & 151 & 60.6 & \multirow{3}{*}{0.11} & $A A+G A$ vs. GG & 0.06 & $1.49(1.01-2.20)$ \\
\hline GA & 78 & 45.1 & 87 & 34.9 & & AA vs. $G A+G G$ & 1.00 & $0.91(0.35-2.40)$ \\
\hline \multirow[t]{3}{*}{$\mathrm{AA}$} & 7 & 4.0 & 11 & 4.5 & & AA vs. GG & 1.00 & $1.09(0.41-2.92)$ \\
\hline & & & & & & GA vs. GG & $0.04^{*}$ & $1.54(1.03-2.30)$ \\
\hline & & & & & & AA vs. GA & 0.62 & $0.71(0.26-1.92)$ \\
\hline \multicolumn{9}{|c|}{ IL-21R rs2285452 allele: } \\
\hline G & 254 & 73.4 & 389 & 78.1 & & & & \\
\hline$A$ & 92 & 26.6 & 109 & 21.9 & & A vs. G & 0.12 & $1.29(0.94-1.78)$ \\
\hline
\end{tabular}

${ }^{a} \chi^{2}$ test, ${ }^{b}$ Fisher's exact test, ${ }^{*} p<0.05$. 
Table IV. Analysis of clinical parameters in relation to IL-21 and IL-21R genotypes

\begin{tabular}{|c|c|c|c|c|c|c|c|c|c|}
\hline \multirow[t]{2}{*}{ Genotype } & \multirow[t]{2}{*}{$N$} & \multicolumn{2}{|c|}{ Age at onset [years] } & \multicolumn{2}{|c|}{$\begin{array}{l}\text { Rheumatoid } \\
\text { factor positive }\end{array}$} & \multicolumn{2}{|c|}{ Erosive RA } & \multicolumn{2}{|c|}{$\begin{array}{l}\text { Extra-articular } \\
\text { manifestations }\end{array}$} \\
\hline & & Mean \pm SD & $P$-value ${ }^{a}$ & $\%$ & $P$-value ${ }^{b}$ & $\%$ & $P$-value ${ }^{b}$ & $\%$ & $P$-value ${ }^{b}$ \\
\hline \multicolumn{10}{|c|}{ IL-21 rs2221903: } \\
\hline $\mathrm{TT}$ & 174 & $47.04 \pm 13.57$ & \multirow{3}{*}{0.86} & 75.45 & \multirow{3}{*}{0.89} & 81.50 & \multirow{3}{*}{0.61} & 18.97 & \multirow[t]{3}{*}{0.68} \\
\hline $\mathrm{CT}$ & 193 & $47.49 \pm 13.21$ & & 74.60 & & 78.24 & & 15.54 & \\
\hline $\mathrm{CC}$ & 55 & $48.22 \pm 12.28$ & & 77.78 & & 83.33 & & 16.36 & \\
\hline \multicolumn{10}{|c|}{ IL-21 rs6822844: } \\
\hline GG & 313 & $47.54 \pm 13.36$ & \multirow{3}{*}{0.16} & 75.66 & \multirow{3}{*}{0.85} & 79.42 & \multirow{3}{*}{0.78} & 17.89 & \multirow[t]{3}{*}{0.34} \\
\hline $\mathrm{GT}$ & 103 & $46.46 \pm 12.84$ & & 74.00 & & 82.52 & & 13.59 & \\
\hline $\mathrm{TT}$ & 6 & $56.17 \pm 9.77$ & & 83.33 & & 83.33 & & 33.33 & \\
\hline \multicolumn{10}{|c|}{ IL-21 rs6840978: } \\
\hline $\mathrm{CC}$ & 287 & $47.43 \pm 13.39$ & \multirow{3}{*}{0.20} & 75.54 & \multirow{3}{*}{0.86} & 79.30 & \multirow{3}{*}{0.63} & 16.38 & \multirow[t]{3}{*}{0.85} \\
\hline $\mathrm{CT}$ & 123 & $46.71 \pm 12.55$ & & 74.38 & & 82.93 & & 18.70 & \\
\hline $\mathrm{TT}$ & 12 & $53.75 \pm 15.12$ & & 81.82 & & 75.00 & & 16.67 & \\
\hline \multicolumn{10}{|c|}{ IL-21R rs2285452: } \\
\hline GG & 239 & $47.18 \pm 12.56$ & \multirow{3}{*}{0.88} & 77.49 & \multirow{3}{*}{0.33} & 80.17 & \multirow{3}{*}{0.29} & 17.15 & \multirow[t]{3}{*}{0.79} \\
\hline $\mathrm{GA}$ & 165 & $47.58 \pm 14.30$ & & 71.60 & & 78.79 & & 17.58 & \\
\hline AA & 18 & $48.67 \pm 11.81$ & & 82.35 & & 94.44 & & 11.11 & \\
\hline
\end{tabular}

${ }^{a}$ Kruskal-Wallis test, ${ }^{b} \chi^{2}$ test.

rameters of RA. There were no significant associations between the studied genotypes and age of disease diagnosis, rheumatoid factor, extra-articular manifestations and joint erosions (Table IV).

\section{Discussion}

In this study we examined the genetic polymorphisms in genes coding IL-21 and IL-21R in patients with RA. Our results showed no significant differences in the distribution of the studied genotypes between RA patients and controls, suggesting that IL-21 SNPs are not the genetic loci predisposing to RA development. We also compared the distribution of studied genotypes between patients with disease remission (DAS28 $\leq 2.5$ ) and patients with the active form of disease (DAS28 > 2.5). Our results indicated an increased frequency of rs2221903 CT and CC genotypes in patients with the active form of RA. Previous studies have revealed that IL-21 is a cytokine which plays a significant role in the pathogenesis of RA.

Li et al. have shown that IL-21 induces T-cell activation and proinflammatory cytokine secretion in RA. These authors also reported that IL-21R was overexpressed in the inflamed synovial membranes and in peripheral blood or synovial fluid leukocytes of RA patients [18]. In another study, Xing et al. found that IL-21 can promote the proliferation of synovial tissue and proinflammatory cytokine production in RA patients [19]. Numerous other studies have revealed the important role of IL-21 in RA activity. Rasmussen et al., Sglunda et al. and Liu et al. observed that IL-21 serum concentrations were significantly higher in RA patients than in healthy controls and correlated with DAS28 values $[8,20,21]$.

IL-21 supported B cell activation, proliferation and antibody secretion via the IL-21R pathway. Kwok et al. reported that IL-21 was up-regulated in the synovium, synovial fluid, and serum of patients with RA and in the synovium and serum of mice with collagen-induced arthritis (CIA), an animal model of RA [22]. IL-21 induced RANKL expression in mixed joint cells and CD4+ $T$ cells from mice with CIA and in CD4+ T cells and fibroblast-like synoviocytes from patients with RA. Moreover, IL-21 enhanced in vitro osteoclastogenesis without the presence of RANKL-producing cells and by inducing RANKL expression in CD4+ $T$ cells and fibroblast-like synoviocytes. Sakuraba et al. found that IL-21 receptor knockout mice were resistant to the development of CIA, and IL-21 receptor expression on B cells, but not on T cells, was essential for the development of CIA [23].

Maiti et al. evaluated associations between rs6822844 and celiac disease, rheumatoid arthritis, type 1 diabetes mellitus, primary Sjögren's syndrome, and systemic lupus erythematosus. 
These authors observed an association between rs6822844 and multiple autoimmune diseases [24].

So far the association between $I L-21$ gene polymorphisms and IL-21 serum levels has not been widely investigated. Li et al. found that IL-21 rs2221903 was by interaction with IL-21R rs3093301 associated with serum IL-21 levels in patients with chronic hepatitis B virus infection [9]. Lan et al. found that IL-21 rs2055979 correlated with IL-21 serum levels in patients with systemic lupus erythematosus [10]. Unfortunately the association between IL-21 gene polymorphisms and the expression or the function of the IL-21 gene was not investigated. Our study is also limited by the lack of measurement of serum IL-21 levels and lymphocyte IL-21 mRNA expression levels in patients with different IL-21 genotypes.

The above studies have indicated that IL-21 is a cytokine which plays an important role in RA pathogenesis, especially in RA activity. The results of our study suggest that IL-21 gene polymorphisms are not genetic risk loci for RA susceptibility, whereas the IL-21 rs2221903 polymorphism is associated with RA activity. Probably the differences in IL-21 synthesis associated with this polymorphism or linkage with other gene polymorphisms may influence the disease activity in RA patients. However, this hypothesis requires further investigation.

\section{Conflict of interest}

The authors declare no conflict of interest.

\section{References}

1. Strengeil M, Sareneva T, Foster D, Julkunen I, Matikainen S. IL-21 upregulates the expression of genes associated with innate immunity and Th1 response. J Immunol 2002; 169: 3600-5.

2. Asao H, Okuyama C, Kumaki S, et al. Cutting edge: the common gamma-chain is an indispensable subunit of the IL-21 receptor complex. J Immunol 2001; 167: 1-5.

3. Terrier B, Geri G, Chaara W, et al. Interleukin-21 modulates Th1 and Th17 responses in giant cell arteritis. Arthritis Rheum 2012; 64: 2001-11.

4. Leonard WJ. Cytokines and immunodeficiency diseases. Nat Rev Immunol 2001; 1: 200-8.

5. Monteleone G, Pallone F, MacDonald TT. Interleukin-21: a critical regulator of the balance between effector and regulatory T-cell responses. Trends Immunol 2008; 29: 290-4.

6. Niu X, He D, Zhang X, et al. IL-21 regulates Th17 cells in rheumatoid arthritis. Hum Immunol 2010; 71: 334-41.

7. Jang E, Cho SH, Park H, Paik DJ, Kim JM, Youn J. A positive feedback loop of IL-21 signaling provoked by homeostatic CD4+CD25- T cell expansion is essential for the development of arthritis in autoimmune $\mathrm{K} / \mathrm{BxN}$ mice. J Immunol 2009; 182: 4649-56.

8. Rasmussen TK, Andersen T, Hvid M, et al. Increased interleukin 21 (IL-21) and IL-23 are associated with increased disease activity and with radiographic status in patients with early rheumatoid arthritis. J Rheumatol 2010; 37: 2014-20.
9. Li N, Zhu Q, Li Z, et al. IL21 and IL21R polymorphisms and their interactive effects on serum IL-21 and IgE levels in patients with chronic hepatitis B virus infection. Hum Immunol 2013; 74: 567-73.

10. Lan Y, Luo B, Wang JL, Jiang YW, Wei YS. The association of interleukin-21 polymorphisms with interleukin-21 serum levels and risk of systemic lupus erythematosus. Gene 2014; 538: 94-8.

11. Motawi T, Salman T, Shaker O, Abdelhamid A. Association of polymorphism in adiponectin ( $+45 \mathrm{~T} / \mathrm{G})$ and leptin (-2548 G/A) genes with type 2 diabetes mellitus in male Egyptians. Arch Med Sci 2015; 11: 937-44.

12. Sobjanek M, Zabłotna M, Michajłowski I, Nedoszytko B, Lesiak A. Nowicki R-308 G/A TNF-alpha gene polymorphism influences the course of basal cell carcinoma in a Polish population. Arch Med Sci 2015; 11, 3: 599-604.

13. Michele S, Salluzzo MG, Calogero AE, Raffaele F, Bosco P. Association study of COX-2 (PTGS2) $-765 \mathrm{G} / \mathrm{C}$ promoter polymorphism by pyrosequencing in Sicilian patients with Alzheimer's disease. Arch Med Sci 2014; 10: $1235-8$.

14. Łoniewska B, Kaczmarczyk M, Clark JS, Gorący I, Horodnicka-Józwa A, Ciechanowicz A. Association of functional genetic variants of A-kinase anchoring protein 10 with QT interval length in full-term Polish newborns. Arch Med Sci 2015; 11: 149-54.

15. Aletaha D, Neogi T, Silman AJ, et al. Rheumatoid arthritis classification criteria: an American College of Rheumatology/European League against Rheumatism collaborative initiative. Arthritis Rheum 2010; 62: 2569-81.

16. Felson DT, Anderson JJ, Boers M, et al. The American College of Rheumatology preliminary core set of disease activity measures for rheumatoid arthritis clinical trials. The Committee on Outcome Measures in Rheumatoid Arthritis Clinical Trials. Arthritis Rheum 1993; 36: 729-40.

17. Humphreys JH, Symmons DP. Post publication validation of the 2010 American College of Rheumatology/ European League Against Rheumatism classification criteria for rheumatoid arthritis: where do we stand? Curr Opin Rheumatol 2012; 25: 157-63.

18. Li J, Shen W, Kong K, Liu Z. Interleukin-21 induces T-cell activation and proinflammatory cytokine secretion in rheumatoid arthritis. Scand J Immunol 2006; 64: 515-22.

19. Xing R, Yang L, Jin Y, et al. Interleukin-21 induces proliferation and proinflammatory cytokine profile of fibroblast-like synoviocytes of patients with rheumatoid arthritis. Scand J Immunol 2016; 83: 64-71.

20. Sglunda O, Mann HF, Hulejová $H$, et al. Decrease in serum interleukin-21 levels is associated with disease activity improvement in patients with recent-onset rheumatoid arthritis. Physiol Res 2014; 63: 475-81.

21. Liu R, Wu Q, Su D, et al. A regulatory effect of IL-21 on T follicular helper-like cell and B cell in rheumatoid arthritis. Arthritis Res Ther 2012; 14: R255.

22. Kwok SK, Cho ML, Park MK, et al. Interleukin-21 promotes osteoclastogenesis in humans with rheumatoid arthritis and in mice with collagen-induced arthritis. Arthritis Rheum 2012; 64: 740-51.

23. Sakuraba K, Oyamada A, Fujimura K, et al. Interleukin-21 signaling in B cells, but not in T cells, is indispensable for the development of collagen-induced arthritis in mice. Arthritis Res Ther 2016; 18: 188.

24. Maiti AK, Kim-Howard X, Viswanathan P, et al. Confirmation of an association between rs6822844 at the II2-II21 region and multiple autoimmune diseases: evidence of a general susceptibility locus. Arthritis Rheum 2010; 62: 323-9. 